\title{
フラーレンとスポーツ用品
}

高 倉剛*

\section{Fullerene and Sporting Goods}

Tsuyoshi TAKAKURA (Frontier Carbon Corporation, 1-1 Kurosakishiroishi, Yahatanishi-ku, Kitakyushushi 806-0004 JAPAN)

Fullerene is a typical Nano-Carbon Material with interesting properties. Progressive developments of fullerene studies in the last decade suggest that many of them can be applied for practical technologies in a wide range of areas including information and electronics technology, environment, energy, materials and bio-medical fields. Examples include IT devices, photosensitive material, lithium ion battery, diagnostic agent, and improved materials as new resources for such as composite additives, and more studies are further conducted to utilize the chemical and physical properties of fullerenes.

While high production cost of fullerenes has been the main obstacle in the development of fullerene market, the first sporting goods as a fullerene product was introduced to consumer market in 2003 following the launching of fullerene mass production in 2002 by Frontier Carbon Corporation. Since then, a series of sporting goods have been commercialized in various items, and it is expected that fullerene products are to be applied to different industries in the very near future.

Key Words : Fullerene, Nano-Carbon, Hollow Sphere, Combustion Method, Composite Material, GFRP, CFRP

\section{1.は じめ め}

フラーレンは炭素原子のみからなり, 中空構造をもった ナノサイズの「炭素分子」である(図 1)。代表的なナノカ ーボン材料として, 様々な分野での応用展開が期待されて いる.このような炭素分子の存在は1970年に予想され1), 1985 年星間分子の研究の中で初めて実験的に確認され $た^{2)}$. 人工合成が 1990 年に成功 ${ }^{3)} し て 以$ 来, 日米欧を中 心に精力的な研究が行われ球状炭素分子としての特徽的性 質が次々と明らかになった。溶媒に可溶で純品に精製でき る上に化学修飾が可能であり ${ }^{4)}$ ，これらを原料とした新規 材料の創製と共に，添加剤として従来材料の高機能化が可 能であることが知られ，広い用途分野で有用性が確認され ている. 2002 年から工業生産が始まったのを契機に 2003 年には最初のフラーレン商品が上市され, 今後多くの産業 分野に㧍いてフラーレンの応用展開が本格化すると期待さ れている. 本稿ではスポーツ用品へのフラーレンの適用例 と今後のフラーレンの実用化について言及したい。

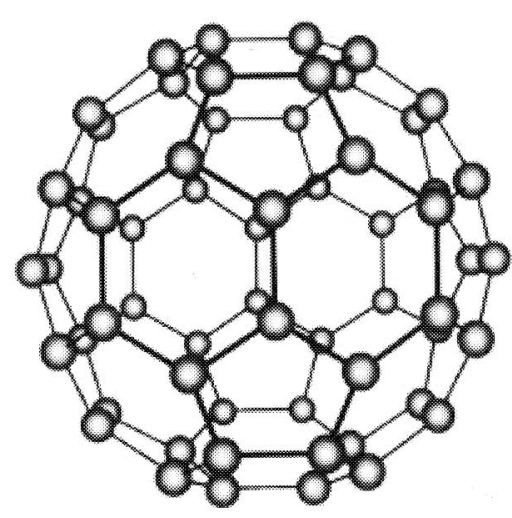

図 $1 \quad \mathrm{C}_{60}$ の炭素骨格

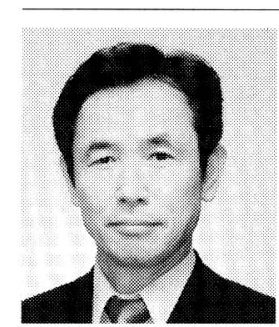

*フロンティアカーボン(株)製造センター( -0004 北九州市八幡西区黑崎城石 1-1) 副社 長・製造センター長. 昭和 50 年, 国立久留米 工業高等専門学校工業化学科卒業. 同年, 三 菱化成工業(秼) (現三菱化学(株)) 入社, 現在フロ ンティアカーボン(株). 専門は, 化学工学, 石 炭化学(ピッチ化学). 所属学会: 化学工学会, 炭素材料学会, 火薬学会 


\section{2. フラーレンの大量生産}

従来フラーレンは高価であった。つい数年前まで金より も高い価格で売られ，また供給量が少なかったために，検 討される範囲, 対象も限られていた。

フロンティアカーボン株式会社 (以下 F C C と略) は, 2002 年 5 月に年産 $400 \mathrm{~kg}$ の製造能力を有するパイロット プラントを，さらに翌2003年 5 月からは年産 $40 \mathrm{t}$ の能力 を持ったスケールアッププラント（図２）の稼動を開始し， フラーレンおよびその周辺素材の量産・低価格化を確立す ることで新規基盤素材としてのフラーレンの実用化に取り 組んでいる。

フラーレン製造プロセスは大きく分けると, (1)フラーレ ン合成ならびにそのフラーレンが含有されたスス (Soot)の 製造プロセス，(2)このススから溶媒不溶な成分, 並びに可 溶な不純物を取り除き，製品となるフラーレン類 $\left(\mathrm{C}_{60}\right.$, $\mathrm{C}_{70}$, 高次フラーレンの混合したミックスフラーレン以下 $\mathrm{MF}$ と略す)を分離・精製するプロセス, (3)カラム分離技 術などを駆使し, $\mathrm{MF}$ から $\mathrm{C}_{60}, \mathrm{C}_{70}$ 等各フラーレン単体を 得る単離プロセス，さらに(4)市場のニーズに合わせてフラ ーレン誘導体を合成あるいはフラーレンを各種媒体に分散 するプロセス等から成る.

(1)のフラーレンを含有したススの製造に関して, FCC は炭化水素を原料にした燃焼法を実用化している。燃焼法 の優れた点は連続プロセスであり大量生産に向いているこ と, また原料として安価な炭化水素を利用できることであ る.ススから如何にフラーレンを抽出し分離・精製するか, (2)および(3)のプロセスもススの製造と同様に実際の大量生 産において極めて重要である. 抽出・分離・精製の全ての 工程において従来に比べ大幅に低コスト化が可能なプロセ スが必須であり，プロセス及び溶媒の選択，使用済溶媒の 回収・再利用に至るまでトータルとして最適なプロセスの 選択が欠かせない5).

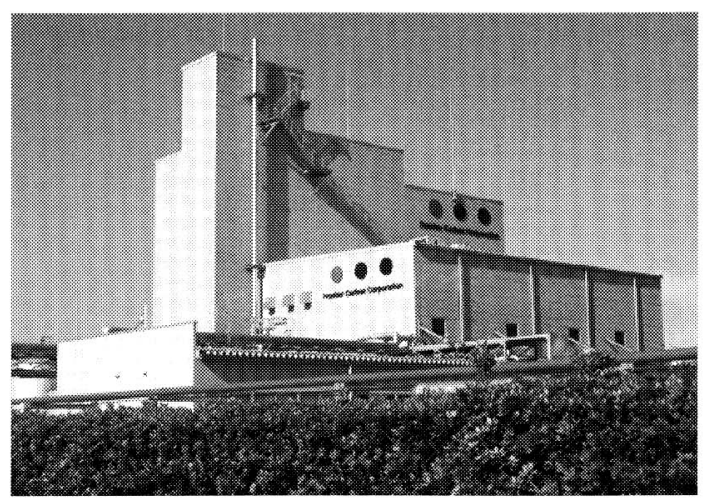

図 2 フラーレン量産工場

\section{3. フラーレンの物性及び応用展開とスポーツ用品}

フラーレンはダイヤモンド，グラファイトに次ぐ第三の
炭素同素体であるが，表 1 に示すとおり有機溶媒に可溶で ある ${ }^{6-9)}$ 。また，昇華性を示す ${ }^{10)}$ ，という独特の特性を持 つ唯一の純粋な「炭素分子」である. H. S. Chenらはフラ ーレンを窒素雰囲気中で昇温すると $450{ }^{\circ} \mathrm{C}$ 付近から指数関 数的に減量が始まり, $700{ }^{\circ} \mathrm{C}$ までに約 $80 \%$ 以上が減量す ること(図 3 )を示している。また，昇温条件を変更した検 討から昇華熱 $(\Delta \mathrm{Hs}$ )を求め，フラーレンの $\Delta \mathrm{Hs}$ は的 40 $\mathrm{kcal} / \mathrm{mol}$ であること，またこれはグラファイトの $\Delta \mathrm{Hs}$ $170 \mathrm{kcal} / \mathrm{mol}$ よりも小さいとしている ${ }^{10)}$.この昇華する性 質は分離・精製に利用されている。また，フラーレンは化 学および熱的に安定で壊れにくい分子であり, 光エネルギ 一を吸収し，電子受容性が高く，優れたラジカル補足能を 有している。ラジカル補足能による, 熱安定性向上の $\mathrm{FCC}$ 測定例を図 4 に示す。即ち，ポリアセタール樹脂 (POM)の耐熱安定剂として, Irganox $1010^{\circledR}$ を添加したも のに対し,フラーレンは添加量に比例して耐熱性が向上し, しかも, Irganox $1010^{\circledR} よ り$ 効果があることが判る。これ は，熱により発生したラジカルがフラーレンにより捕捉さ 表 1 フラーレンの溶解度

溶解度 $\mathrm{mg} / \mathrm{ml}$

\begin{tabular}{l|r|r|r|r}
\hline & \multicolumn{3}{|c}{$\mathrm{C}_{60}$} & \multicolumn{2}{c}{$\mathrm{C}_{70}$} \\
\hline トルエン & 2.9 & $6)$ & 1.4 & $9)$ \\
\hline ベンゼン & 1.5 & $6)$ & 1.3 & $9)$ \\
\hline 0-ジクロルベンゼン & 2.5 & $6)$ & 36 & $9)$ \\
\hline 四塩化炭素 & 0.32 & $7)$ & 0.12 & $9)$ \\
\hline ジクロロメタン & 0.26 & $7)$ & 0.08 & $9)$ \\
\hline シクロヘキサン & 0.04 & $7)$ & 0.08 & $9)$ \\
\hline アセトン & 0.001 & $7)$ & 0.002 & $9)$ \\
\hline イソプロパノール & 0.002 & 8 & 0.002 & $9)$ \\
\hline
\end{tabular}

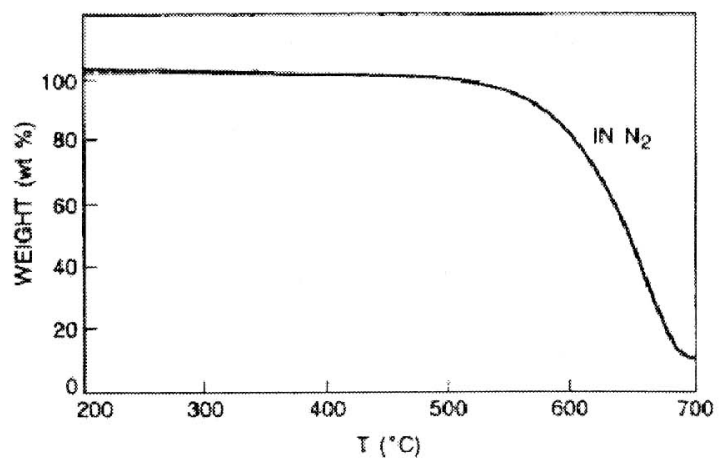

図 $3 \mathrm{C}_{60}$ の TGA 分析 (昇温速度 $=1.2^{\circ} \mathrm{C} / \mathrm{min}$ )

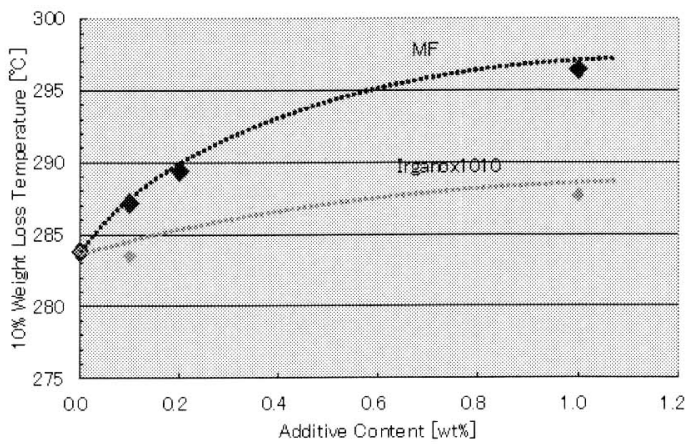

図 4 POMのフラーレン添加による耐熱性向上 
れ，ポリマーの分解が抑制されたものと推測される。他に も, エネルギー分野, IT 分野, 医薬品や診断薬などバイ オ分野への応用等に加えて, フラーレンが大量に利用でき る基盤が出来てきたことから，さらに広範な分野で応用研 究が加速しており, ポリマー, ゴム, 複合材への添加剂, 潤滑用途など実用化の例が増えてきている(図 5 ). そとんな 中で，いち早く商品化されたのがスポーツ分野である.

\section{1 ボウリングのボール}

2003 年 1 月, 世界初のフラーレン入り商品として具体

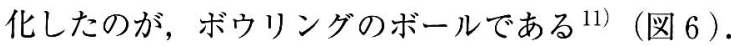

\section{2 ゴルフクラブ}

2003 年 7 月には, チタンにフラーレンを添加したクラ ブヘッドを有するゴルフタラブが登場 ${ }^{12}$ ）（図 7 ）。チタン の中にフラーレンを均等に配合することにより，金属強 度・疲労特性がアップ. 結果, ヘッドのたわみを最大限に 引き出す極薄ヘッド構造とし, 従来に比べ飛距離アップを 実現している.

2004 年 10 月には，フラーレンを添加した樹脂を用いた ガラス繊維強化複合材料 (GFRP) をシャフトに採用したゴ ルフクラブが発表され, 発売は翌年 2 月より開始された ${ }^{13)}$. 軽量で，しかも強さとガラス繊維特有の粘りを両立させた クラブである。

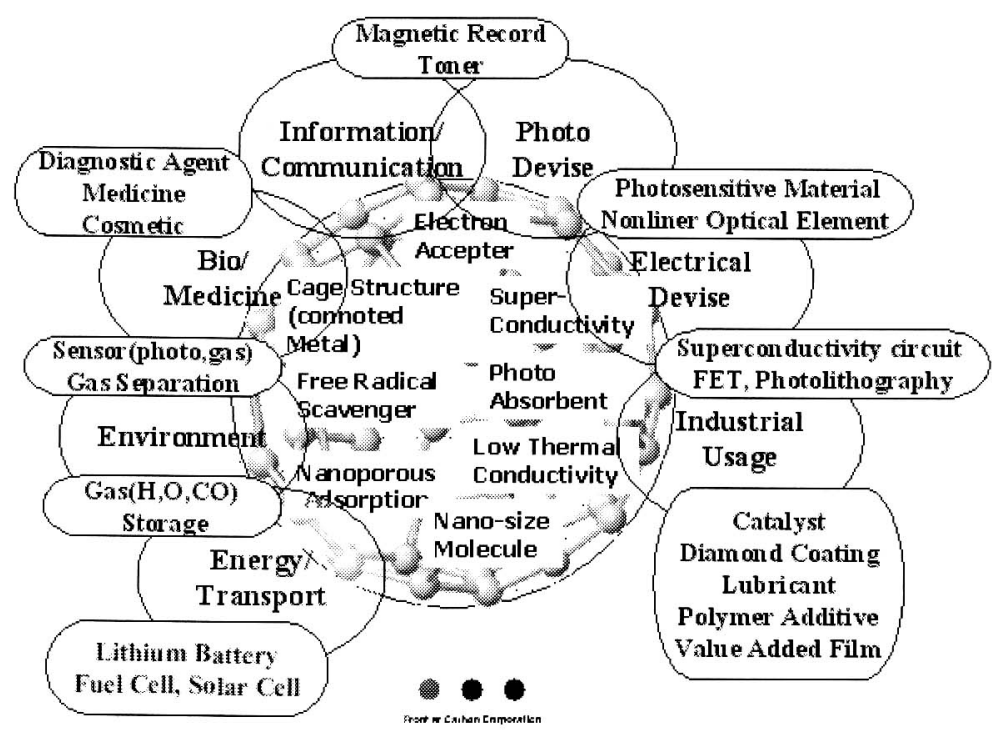

図 5 フラーレンの特性とその応用

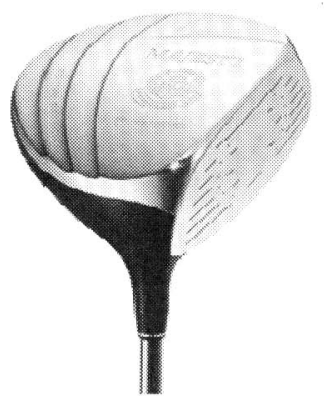

図 7 ゴルフタラブ(ヘッド) (マルマン株式会社より提供)
一方，2005年 2 月に炭素繊維強化複合材料 (CFRP) のマ トリックス樹脂にフラーレンを添加したシャフトならびに

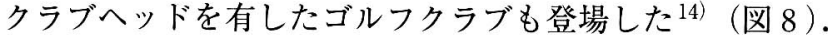
更に，2006年 1 月，および 8 月には，それぞれ別のメー カーよりフラーレンを配合したCFRPをシャフトに用いた ゴルフクラブが発売された ${ }^{15)}$ (図 9)。これらは，いずれ もフラーレンを添加することにより，軽量化に加え更なる 特性改善を狙った例である．また，複数のメーカーでの採 用は，フラーレンの効果が認知されてきた証としても捉え られる。

\section{3 ラケット類}

2004年 11 月に，バドミントンラケット(図 10)，2005年 2 月には，硬式テニスラケット，軟式テニスラケットと相 次いで発売された ${ }^{14)}$.

これらはいずれもフラーレンを添加したCFRPでフレー ムとシャフトができており，バドミントンラケットについ ては，メーカーのコメントでは，

(1)軽量で強い構造のラケット(2) $15 \%$ 軽量化して「トッ プライト設計」が可能(3)耐衝撃強度 $30 \%$ 及び耐久性 $10 \%$ の向上(4)反発性能 $5 \%$ \%アップにより，スマッシュ，ド ライブのスピードがさらに加速することになる.

テニスのラケットも同様な期待効果である.

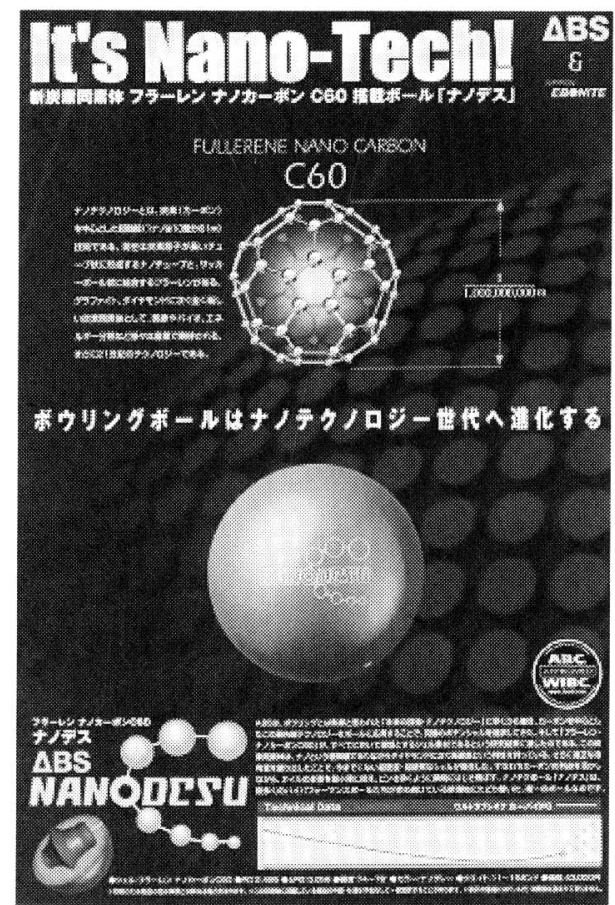

図 6 ボウリングのボール

（株式会社アメリカンボウリングサービスより提供） 


\section{4 ガット}

2005 年 2 月, バドミントン及びテニスのガットが発売 された ${ }^{16)}$ 。これは, 耐久性アップ, 反発力アップ, に加 え，かつてない高音という特徎を持っているとのことであ る. スポーツの分野では音や打感といった感性の部分も重 要な要素となる.

\section{5 スキーワックス}

2005 年 2 月，フラーレンの潤滑性を生かしたスキーワ ックスが発表された ${ }^{17)}$.

3.6 スノーボード

2005年春, CFRPを用いたスノーボードが発表された ${ }^{14)}$.

\section{7 ゴルフボール}

2006 年 4 月，ゴルフボールが発売された ${ }^{18)}$ (図11)。こ れは，高弾性エラストマーにフラーレンを配合し，過剩な バックスピンの減少による飛距離アップと打球感の改良を 行っている。

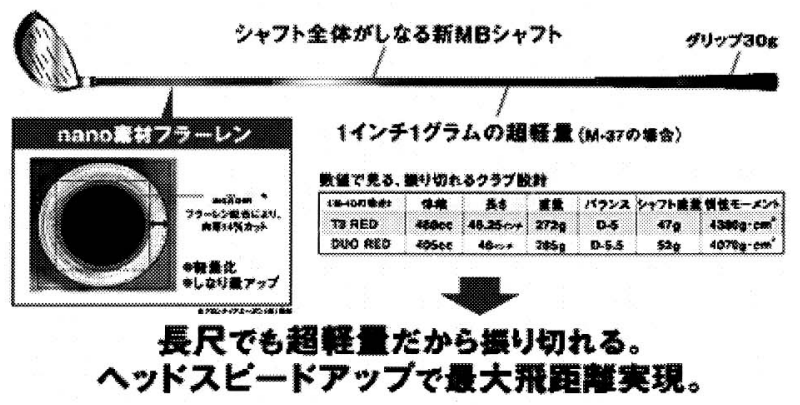

図 9 ゴルフクラブ(シャフト)

（横浜ゴム株式会社より提供）

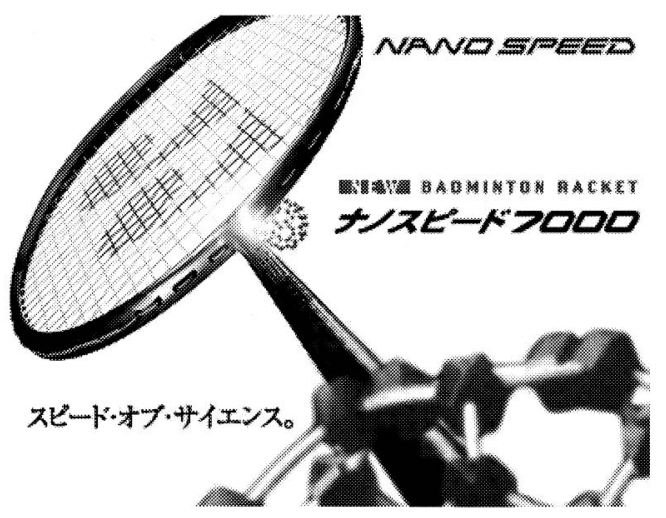

図 10 バドミントンラケット （ヨネックス株式会社より提供）

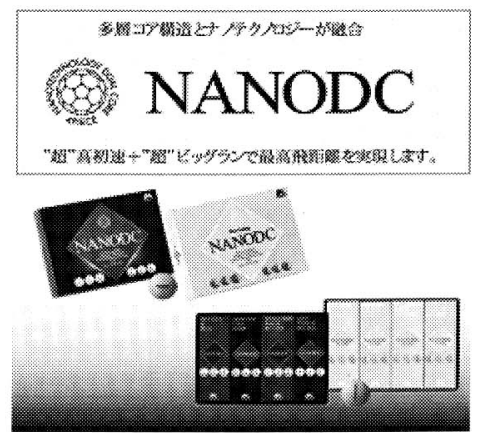

\section{8 その他スポーツ用品}

その他スポーツ用途として検討がなされているものとし て卓球ラケットへの適用特許 19,20$)$ が出ている.

\section{4. 工業製品への適用}

フラーレンを添加することで，従来の材料でも耐熱性向 上が図れる FCCの測定例を図 12 に示す。従来より，樹脂 にカーボンブラックを添加すると耐熱性が向上することが 知られているが，フラーレンはカーボンブラックよりその 効果が大きい. 図 12 は 4 種類の樹脂について MF及び三 菱カーボンブラック＃30 ${ }^{\circledR}$ をれぞれ $1 \%$ 添加した場合と 無添加の試料について，重量が10\%減となる温度を測定 した結果を示している．カーボンブラックおよび MFを加 えた試料では無添加のものに比べて $10 \%$ 減量する温度が 上昇し，耐熱性が改善されるがことが判る。また，いずれ の樹脂においても MFのほうがはるかに効果が大きい. MFとカーボンブラックの温度の差を図中に数字で示し た。次に，機械特性向上が図れる FCC 測定例を図 13 に 示す。フラーレンを添加しないエポキシ樹脂に対し，僅か な添加量 (約 $0.1 \sim 1 \%$ ) でも，曲げ強度，弾性率共に向上 が見られる。他に撥水性・撥油性, 潤滑性 ${ }^{21,22)}$ を始めと し種々の特性改善が図られるとともに，使用素材の低減 · 低コスト化，そして長寿命化が可能となる。また，フラー レンの光電機能やラジカル補足機能を応用することによ り，エネルギー分野およびI Tデバイス関連分野において も実際の商品化を目指した検討が加速している。リチウム

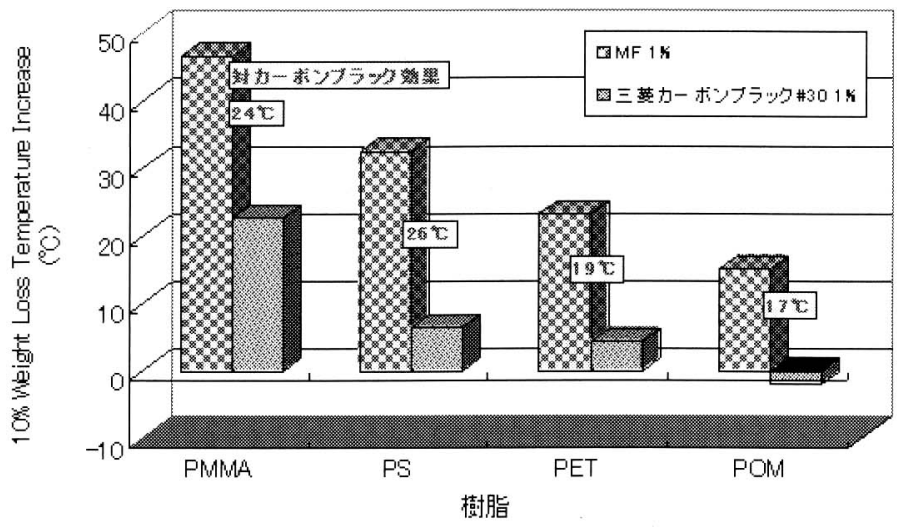

図 12 フラーレン添加による樹脂の耐熱性改善効果

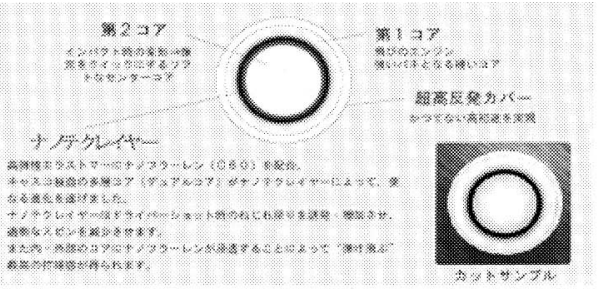

図11 ゴルフボール

（キャスコ株式会社より提供） 


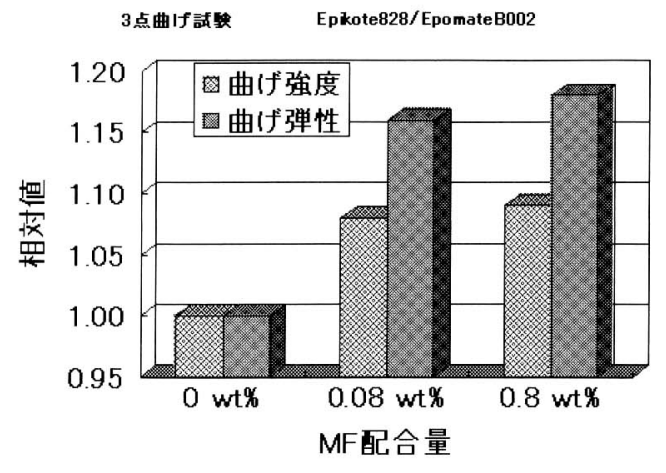

四13 フラーレン添加によるエポキシ樹脂の改質

イオン電池にフラーレンを添加するとエネルギー密度, サ イクル特性, 安全性等が格段に改善され, 燃料電池におい ては広い温度範囲で作動する電解質膜が作成可能となる。 電子ペーパー等の電力源として有望な有機太陽電池につい ては, 実用化に向けた検討が加速している ${ }^{23)}$. 更に, ゴ ム分野への応用としては, 低比重でヒステリシスロスや動 的損失を低減させたゴム組成物や低発熱性で耐久性と転動 抵抗に優れたタイヤ ${ }^{24)}$ ，エラストマーの高減衰性保持確 保 ${ }^{25)}$, エラストマーに添加し安定した半導電性領域の制 御を容易化 ${ }^{26)}$, 制震, 免震用途の防振ゴムへの適用 ${ }^{27)}$ 等 が特許として, 出されている.

これらの技術は今後数年で市場に出てくる可能性が高 く, 我々の生活をより省エネルギーで安全かつ快適にして くれると期待されている.

\section{5.おわりに}

従来高価で供給量も限られていたフラーレンであるが, この数年で工業生産が本格化し, 特に日本においては潤沢 に使える環境が整ってきた，炭素という無機的性質と，溶 媒に溶け官能基を付与できるといった有機的性質を併せ持 つフラーレンは, 現在は, 主にスポーツ用途で複合材への 添加による，特性向上を主とした商品化が行われている. 今後，工業用製品の登場が待たれるところである.

過去を見れば，新しい素材がスポーツ用途から始まり工 業用途へと展開されることを想定した場合，炭素繊維の例 がある. 1970年代初めスポーツ用途に始まり，ここでそ の性能が認められ，1980年代以降航空機用に展開された のを機に, 耐震補強用, 液晶基板運搬用ロボットアーム, 印刷用ロール，といった産業用途へと順次展開され代替不 可の分野を形成し，今世紀に入り年々需要が伸びている.

これが新素材の展開の成功例と考えるとフラーレンも同 様な足跡をたどるのではと期待するところである.

スポーツ用品の材料開発は日進月歩である. 例えば，テ ニスやバドミントンのラケットは従来は竹や木製であった ものがアルミ製から今はCFRPに代わり, 性能も格段に向 上している。 この傾向は今後も続くであろうし, 素材鞈
の延長上に工業製品開発があるとすればこの総説が材料開 発や商品化の一助となることを期待するものである.

省資源・省エネルギーに貢献でき，環境に優しい新素材 であるフラーレンの実用化に対し，2005年 9 月年愛知万 博で「愛・地球賞」を受賞し，また，2005年 10 月に北九州 市より「エコプレミアム製品」に登録されたことを付記す る.

\section{References}

1) Oosawa, E.: Kagaku, 25, 850 (1970)

2) Kroto, H.W.; Heath, J.R.; O' Brien, S.C.; Curl, R.F.; Smalley, R. E.: Nature, 318, 162 (1985)

3 ) Kratschmer, W.; Lamb, L.D.; Fostiropoulos, K.; Huffman, D. R.: Nature, 347, 354 (1990)

4) Murayama, H.: Kagakukougaku, 69, 32 (2005)

5 ) Arikawa, M.: Tanso, 224, 299 (2006)

6 ) Scrivens, W. A.; Tour, J. M.: J. Chem. Soc., Chem. Commun, 15, 1207 (1993)

$7)$ Ruoff, R. S.; Tse, D. S.; Malhotra, R.; Lorents, D. C.: J. Phys. Chem., 97, 3379 (1993)

8 ) Heymann, D.: Carbon, 34, 627 (1996)

9 ) Siveraman, N.; Dhamodaran, R.; Kaliappan, I.; Srinivasan, T. G.; Vasudeva Rao, P.R.; Mathews, C.K.: "Fullerenes", p.156 (1994)

10) Chen,H.S.; Kortan, A. R.; Haddon, R.C.; Fleming, D. A.: J. Phys. Chem., 96, 1016 (1992)

11) ABS 社 HP: http://www.absbowling.co.jp/products/balls/ index.html

12）マルマン社 HP: http://www.maruman.co.jp/

13）ダイワ精工社 HP: http://www.daiwaseiko.co.jp/

14）ヨネックス社 HP: http://www.yonex.co.jp/index.html

15）横浜ゴム社 HP: http://www.yrc.co.jp/

16）ゴーセン社 HP: http://www.gosen.jp/

17）マツモトワックス社 HP: http://www.matsumotowax.com/

18）キャスコ社 HP: http://www.kascogolf.com/jp/closeup/closeup28.html

19) Tamasu, K.: Jpn. Kokai Tokkyo Koho, 2005-6924 (2005)

20) Tamasu, K.: Jpn. Kokai Tokkyo Koho, 2005-118223 (2005)

21) http://www.syba.co.jp/nagai/

22) http://www.bardahl.co.jp/index.htm

23）産総研HP: http://www.aist.go.jp/aist_j/press_release/pr2005/ pr20050127/pr20050127.html

24) Aoki, S .; Kasai,T.: Jpn. Kokai Tokkyo Koho 2005-23239 (2005)

25) Takamatsu, S .; Kasai, T.: Jpn. Kokai Tokkyo Koho, 2005-82608 (2005)

26) Yoshikawa, H.; Kasai, T.: Jpn. Kokai Tokkyo Koho, 2005-179590 (2005)

27) Miyaji, H.; Nakanishi, S.; Kasai, T.: Jpn. Kokai Tokkyo Koho, 2006-131819 (2006)

\section{日本語表記参考文献}

1 ）大澤映二：化学, 25, 850 (1970)

4) 村山英樹：化学工学, 69, 32 (2005)

5 ) 有川峯幸：炭素, 224, 299 (2006)

19）田枡公彦：特開2005-6924(2005)

20）田枡公彦：特開2005-118223(2005)

24）青木勢，笠井鉄夫：特開 2005-23239（2005）

25）高松成亮，笠井鉄夫：特開 2005-82608（2005）

26）吉川均，笠井鉄夫：特開 2005-179590（2005）

27）宮路浩忠, 中西臣悟, 笠井鉄夫 : 特開 2006-131819 (2006) 